\title{
Open Government Partnership: Indonesian Transformative Effort to Deal with Corruption
}

\author{
Zakia Nurus Syifa \\ Universitas Airlangga
}

\begin{abstract}
This research seeks to explain the underlying reasons of why Indonesia under Yudhoyono administration joined Open Government Partnership (OGP). Based on the relationship between democracy, corruption, and good governance, this research explores on how corruption had caused negative impacts not only to domestic sphere, but also to Indonesia's international legitimacy which leads to affect the economic growth. Focusing on the process of the OGP initiation, the scope spans from July 2010, when Indonesia was first invited to join this initiative, to September 20, 2011, when Indonesia became one of the eight founding countries to launch OGP in New York. This research suggests that Indonesia joined OGP to help ease the negative impacts of corruption. From the research, there are findings that corruption had caused negative implications in domestic sphere and international legitimacy, which leads to curb Indonesia's potential investment and economic growth.
\end{abstract}

Keywords: democracy, corruption, good governance, open government, OGP, international initiative, international legitimacy, economic growth

Penelitian ini ingin menjelaskan tentang alasan mengapa Indonesia di bawah Presiden Yudhoyono bergabung dengan Open Government Partnership (OGP). Berdasarkan hubungan antara demokrasi, korupsi, dan pemerintahan yang baik, penelitian ini mengeksplorasi bagaimana korupsi memberikan implikasi negatif tidak hanya bagi kondisi domestik Indonesia, tetapi juga legitimasi internasional Indonesia, yang kemudian berpotensi berpengaruh pada pertumbuhan ekonomi. Dengan berfokus pada proses inisiasi OGP, ruang lingkup penelitian ini berawal dari Juli 2010, saat pertama kalinya Indonesia diundang untuk bergabung mendirikan inisiatif ini, hingga 20 September 2011, ketika Indonesia akhirnya menjadi satu dari delapan negara pendiri yang mencanangkan inisiatif OGP di New York. Penelitian ini menyatakan bahwa Indonesia bergabung dengan OGP untuk membantu mengatasi efek negatif dari korupsi. Dari penelitian yang dilakukan, terdapat bukti-bukti bahwa korupsi telah memberikan implikasi negatif bagi kondisi domestik dan legitimasi internasional Indonesia, yang kemudian menghambat potensi investasi dan pertumbuhan ekonomi Indonesia.

Kata-kata kunci: demokrasi, korupsi, pemerintahan yang baik, pemerintahan terbuka, OGP, inisiatif internasional, legitimasi internasional, pertumbuhan ekonomi 
After the downfall of Suharto's New Order in May 1998, Indonesia had begun its re-democratization demanding for democracy and bureaucracy reform (Mujani 2006). This period starting in 1998 onwards is historiographically referred as the reform period (Reformasi). Indonesian government managed to achieve some improvements in democracy, such as by being able to end the singleparty domination, conducted general elections, started its first direct presidential and vice presidential elections, freed the political prisoners, returned the freedom of public expressions, supported decentralization, separated police from military that improve the civil-military relations, ratified United Nations Convention against Corruption (UNCAC) 2003 into Law No. 7 of 2006, established the Corruption Eradication Commission (Komisi Pemberantasan Korupsi, KPK), and legalized Law No. 14 about Public Information Openness (Keterbukaan Informasi Publik, KIP) of 2008.

The improvements mentioned above served as indicators of Indonesia's democratic potential and ongoing process, and it gained appreciation and endorsement from the international community. The support from the international community made Reformasi government confident of democracy and good governance as the source of its identity and international standing for the country.

In December $10^{\text {th }}, 2008$, Indonesia initiated Bali Democracy Forum (BDF), the first intergovernmental forum inclusive for countries in Asia Pacific which regard themselves as democracies or those aspire to be more democratic (Wirajuda 2014, 138). BDF marked a major step on Indonesian democracy, from experiencing to promoting democracy (Erawan n.d.). Democracy is seen as something to be highlighted in Indonesia's foreign policy to show that democracy is indeed working (Sebastian in Wirajuda 2012, 138). BDF claims to successfully produce concrete actions for promoting democracy in the Asia Pacific region. Through BDF, Indonesia also emphasized on the importance of how democracy should be built in the region that based on a 'home-grown' experience, constructed based on nation's own historical experience and cultural conditions, and cannot be imposed from outside (BDF website).

Despite Indonesia's thriving role in advancing democracy in international level, Yudhoyono administration added another feature to his governance, that is, by engaging Open Government 
Partnership (OGP) initiative. OGP is a global initiative to secure countries' commitment to promote transparency, empower citizen, fight corruption, and harness new technologies to strengthen governance (OGP Articles of Governance 2015). Indonesia was one of the eight founding countries, together launched this initiative on September 20, 2011 with United States, Brazil, Mexico, Norway, Philippines, South Africa, and United Kingdom. This research seeks to explain the answer of why Indonesian government under Yudhoyono administration still needs to join OGP, considering the importance of Indonesian progress after 1998.

\section{Indonesia's Corruption Level}

Decentralization is one of the elements of democracy. Assuming that decentralization will guarantee good governance is a fallacy (Sumarto, Suharyadi, dan Arifianto, 2004:1). Even after its redemocratisation in 1998, Indonesia is not automatically free from corruption. Corruption has been deeply rooted in Indonesian society that it pervades in every level of government and is seen as daily practice in almost every aspect of living. People bribe police to get driving license, parents bribe schools to get their kids enrolled, and criminals bribe judges to reduce their sentence at the court. Corruption becomes something latent.

Corruption is defined as the abuse of entrusted power or public officials for private gain (Transparency International). Corrupt practices include offering, giving, receiving or soliciting, directly or indirectly, anything of value to influence improperly the actions of another party (World Bank). In Indonesia, corruption is closely associated with collusion and nepotism. The term is widely known as KKN (Korupsi-Kolusi-Nepotisme). It has a long historical background from Indonesian New Order regime under President Suharto, where KKN was widely practiced by him and his cronies and patronages for about 32 years of his leadership and continued many years after his resignation. Started in 1995, Transparency International has been releasing its Corruption Perception Index (CPI). This index does not represent TI's own assessment on corruption in different countries in the world, but it scores and ranks countries according to the level of corruption that is perceived to exist through surveys (Ang 2011, 9). The CPI ranges from 0 (totally 
corrupt) to 10 (absence of corruption). It is also mentioned that CPI has been influential in raising awareness about corruption and putting corruption as top government's agenda (Ang, 2011:9).

Picture 1: Transparency International's Indonesian Corruption Perception Index 1995-2011

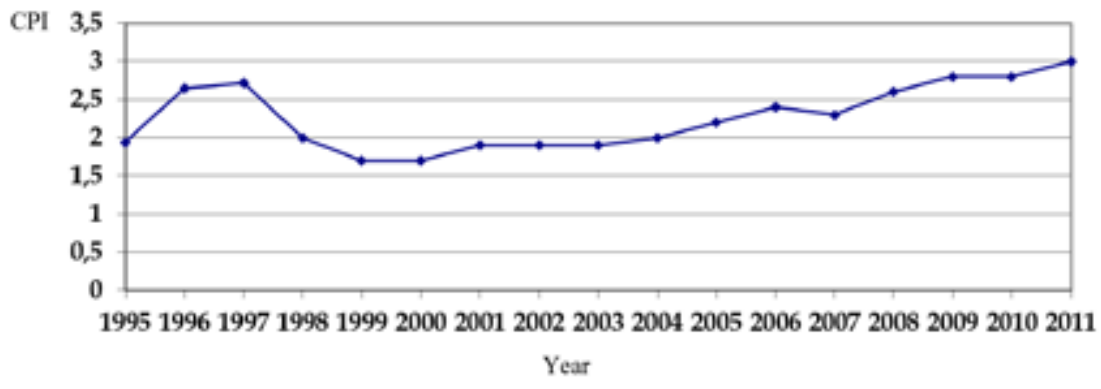

The figure shows that Indonesia's CPI dropped much during 19981999, and slowly improved afterward, with an average index of 2.26 in 17 years (1995-2011). Compared to regional average of 4.1 and global average of 4.6 in 2000 (World Bank 2003, 2), it is considered very modest and it shows very little improvement over the years. Therefore, Indonesia is known as one of the most corrupt countries in the world, ranked as the $41^{\text {st }}$ out of 41 countries in 1995 and the $100^{\text {th }}$ out of 182 countries in 2011. It is also ranked as the fifth most corrupt country in Asia (Transparency International). Whether or not this $\mathrm{CPI}$ is accurate toward the real corruption measurement happening in the country, it has the power to influence individual behaviors, decisions made by potential investors, financial institutions, and international donors; perceptions shape reality (World Bank 2003, 3-4). Studies show that corruption in Indonesia has become worse since 1998 (Sumarto, Suharyadi, dan Arifianto 2004, 8). Many parties fear that along with decentralization, corruption is also decentralized from national to local level (Sumarto, Suharyadi, dan Arifianto, 2004:8). It might be different from corruption happened during Suharto's regime, but it does not necessarily stop.

\section{Negative Implications of Corruption}

The issue of whether corruption 'sands' (hampers) or 'greases' (smoothen) the wheels of economic development has been widely debated (Ang, 2011:16). The 'sands the wheels' hypothesis suggests that corruption hampers economic development, while 'greases the 
wheels' hypothesis suggests that corruption can be beneficial for economic growth in a non-ideal world (Ang 2011, 16). In the past, some scholars argued that corruption could increase economic efficiency in countries with burdensome regulations and a dominant government role in economy (Sumarto, Suharyadi, dan Arifianto 2004, 5-6). Therefore, corruption can avoid bureaucratic rules and trouble. However, most corruption scholars nowadays believe that corruption hinders effort to reduce poverty, degrades social and political institutions, and curbs the economic growth (Sumarto, Suharyadi, dan Arifianto 2004, 6). The government's effort to reduce poverty through various kinds of projects even provides a fertile ground for corruption. Corruption hurts the poor in so many ways ranging from their economy, social, justice, health, and education. It makes the poverty reduction effort ineffective, thus it may hamper national economic development. Corruption also causes a bad public service to Indonesian society due to government ineffectiveness. Indonesia is on the $121^{\text {st }}$ rank of 125 listed countries on public service (Metro TV News, 2014).

Internationally, the release of CPI by TI in the 1995 creates an impact on countries' image and economy. The international shaming following the CPI publication was quite massive. Ranked as one of the worst countries in corruption in Asia and globally, Indonesia had to bear with the label of 'the most corrupted country'. In comparison to Southeast Asian countries, between the category of 'good', 'bad', or 'ugly' governance, Indonesia is categorized as 'ugly', which is worse that 'bad' (Weatherbee 2004). The term 'bad' only defines how the bad governance impacts the internal sphere of the state, but 'ugly' is for something beyond that, where the practice of bad governance in Indonesia has a region-wide impacts: Malaysia has to struggle with thousands of illegal Indonesian immigrants; Australia has to cope with 'boat people' whose passage is facilitated through Indonesia; and Philippines has to be alarmed of Indonesia as a possible breeding ground of militant Islamic terrorist (Weatherbee 2004, 190). Therefore, Indonesia's corruption problem is seen as a threat to the region and put down its image in the eye of international community. It also potentially affects the amount of investment as corruption affects the decisions from the investors coming to Indonesia. These negative implications on Indonesian domestic sphere and international legitimacy give a strong context and urgency to the question of this research. 


\section{Underlying Factors}

From the theoretical framework about state and international organization, there are four possible reasons of why states join internationalorganization:(1)domestic politics; (2) state's sovereignty and conversion of power; (3) legitimacy of the international organization and information transmission; and (4) compliance and effectivity (Hennida 2015, 143-181). This research explores point (1) and point (3) as the underlying reasons of Indonesia's decision to join OGP.

From the point of domestic politics, there are findings that suggest that there was an inadequacy on Indonesia's effort to push good governance agenda before 2011 and there were domestic demands to scale up and accelerate good governance agenda. The ratification of UNCAC in 2003 and legalization of Law No. 14 of 2008 about Public Information Openness has not been working effectively up to 2010. KPK, Indonesian Corruption Eradication Commission did a wonderful job catching the bad guys-corruptors, but this did not necessarily prevent other officials from committing corruption. The Law of Public Information Openness has not started until 2010 based on its annotation, and the supporting instruments were not completed on time. Because this progress was considered to be rather slow, there were domestic demands especially from CSOs to push good governance agenda.

The condition of domestic politics pushed Indonesia to use OGP to continue its effort for good governance. It was confirmed by Kuntoro Mangkusubroto, the Head of UKP4, in his official speech during OGP Declaration in New York, September 20, 2011, "As we believe that our work together will speed up and intensify the promotion of good governance in our own country and throughout the world..." (Mangkusubroto 2011).

From the concept of legitimacy of the international organization and information transmission, there was a need to join membership to increase Indonesia's bargaining power. As the international community through donor/aid agencies such as World Bank, ADB, USAID, etc. demanded for good governance, it is become a constructive idea for Indonesia that a good state has to embrace good governance. Therefore, joining a legitimate international organization/initiative is one of the ways to advance good 
governance agenda in a hope that it will help ease the negative impacts of corruption by creating potential long-term political and economic investment. This argument was confirmed by Tara Hidayat, UKP4 Deputy IV for Strategic Initiative and International Relations, who championed Indonesia's membership in OGP.

\section{The Significance of OGP to Deal with Corruption}

After understanding the underlying factors of Indonesia's decision to join OGP, there are three points of significance on how OGP was expected to deal with corruption. First, OGP can add international pressure to push good governance agenda. Second, OGP can be a momentum to strengthen Indonesia's international legitimacy which was hampered by corruption. Third, OGP can be a long-term political and economic investment.

International organization functions as an intervening variable that influence behavior and outcomes (Hennida 2015, 14). International organization/regime is perceived as something that is capable to consolidate democracy, to keep the ongoing liberal reformation, and to strengthen position toward opposition that all acts against that will be considered against the existing international norms (Mansfield and Pavehouse in Hennida 2015, 143). Every member state is obliged to act according to OGP principle and values. With OGP principles and core values embedded in public policy and agenda, it kept anti-corruption and bureaucracy reform agendas on track. When everything is on track, it is expected that Indonesia could achieve its target faster.

Then, how do we make sure that OGP has the power to make state members oblige its core values and principles? OGP is an institutionalized regime; it was designed with clear mechanism, measurement of progress, reporting and evaluation, and penalty system, as written in OGP Articles of Governance. The operation of OGP is mandated to these four elements: (1) OGP Steering Committee; (2) OGP Annual Conference or Plenary; (3) OGP Support Unit; and (4) OGP Independent Reporting Mechanism (IRM). It secures countries' commitment by implementing certain mechanism within this initiative. 
First, even though it is inclusive to all countries, the candidates of member countries should be eligible first in order to join OGP. The eligibility criteria will be assessed based on a country's fiscal transparency, access to information, disclosures related to public officials, and citizen engagement. The Fiscal Transparency assessment is based on Open Budget Survey. The Access to Information assessment is based on Right2Info.org, a collaboration between Open Society Institute Justice Initiative and Access Info Europe. The Public Officials Asset Disclosure assessment is based on the World Bank Public Official Financial Disclosure. The Citizen Engagement assessment is based on the Economist Intelligence Unit "Democracy Index".

Second, only after being eligible, a state can submit a letter of intent that indicates government's commitment to open government and to participate in OGP, followed by submission of a National Action Plan (NAP) based on OGP standards, which has to be renewed every cycle. It started with one-year-cycle, meaning that every year all OGP member states have to submit its NAP. This NAP will be open for public, not only the citizen of that particular state but to all public in the world. Therefore, anyone can assess, watch, and review whether the state's commitment is ambitious and transformative or not. This publication of NAP will add pressure to a member state to pay a serious attention to fulfill the commitments written in the NAP.

Third, OGP makes it mandatory for member states to collaborate with the CSOs in their own countries in developing and implementing NAP. By making this mandatory, state or government has to listen to the voice of civil societies and be responsive to its citizen. This open collaboration will give a bigger role for CSOs to work together with government, making sure that the government will keep their commitment and providing assistance in the implementation process. This framework provided by OGP platform will also add pressure to government to push the good governance agenda forward.

Fourth, OGP has a self-assessment mechanism and Independent Reporting Mechanism (IRM). IRM will assess the effort and achievement of a member state in OGP. There will be two IRM reports per action plan cycle: midterm report and end-of-cycle 
report ( $\mathrm{Al}^{\prime}$ Afghani 2016). Midterm report assesses the progress on the action plan implementation, while the end-of-cycle report assesses the complete achievement throughout the cycle to see how ambitious an OGP member state is. With this regular evaluation, the target agenda is assessed whether it is achieved or not, and if it is not achieved, the stakeholder would have to find out why and address the problem. The IRM team could also give recommendation for further action, which has to be followed up by the member state in order to reach the satisfaction standard. Fifth, based on IRM result, if a country fails to show the commitment to open government repeatedly in two consecutive action plan cycles or fails to address issues raised by the IRM, the OGP Steering Committee will review its participation in OGP and it may result on membership dismissal action (OGP Articles of Governance).

All aspects in this mechanism gives a sense that Indonesia will always be watched, in a hope that Indonesia will stick to its commitment to openness, transparency, innovation, accountability, and citizen participation in pursuit of good governance. With this pressure, Indonesia cannot take it easy or withdraw its commitment. Instead, it is expected to be the accelerator to advance and to scale up good governance agenda. With binding mechanism, clear measurement, time limit, better collaboration, less unequal power relations between state and non-state actors, and embedded principle and values, it is easier to push the reform agenda forward to combat corruption.

Despite the struggles to fight against corruption and implement the Law of Information Openness, the offer to be one of the founding countries in OGP gave an opportunity for Indonesia to create a momentum to grab international attention. This momentum is an opportunity to showcase the pre-existing and ongoing effort in Indonesia in putting good governance as government'sagenda. When the efforts toward good governance are being kept domestically, no one would know how committed Indonesia is to combat corruption. Therefore, the world needed to know that Indonesia is making progress. There was no better stage than the international institution/regime to tell the world that Indonesia was committed to strive for excellence in openness and bureaucracy reform to combat corruption. When the U.S. offered Indonesia to create OGP platform together in July 2010, the momentum was perfect. This offer added the momentum of domestic ongoing process to openness that had 
been fought by Indonesian government and CSOs over the years since Reformasi 1998. It was the time to seek for support from the international community and to show them that Indonesia is ready to accelerate its progress.

The fact that Indonesia was honored and privileged to be invited by the U.S. to be one of the founding countries gave a big opportunity for Indonesia to be on the spotlight. Being in the spotlight in the global level will put Indonesia in the center of attention, in a hope that it will help ease the impact of declining international legitimacy as a democratic good governance in the eyes of international community.

The recent paradigm in most of the developing world shows that government is no longer become the dominant player in economic activities, but rather to be the provider of enabling environment for private sector (Khan, 1996:419). Many recent studies related to this issue showed that private investment has a larger positive impact on growth than the public investment (Khan et al, 1996, 419). Therefore, it is government's responsibility and investment to create that enabling environment for investment.

Corruption problem resulted in international shaming to Indonesia. Labelled as 'the most corrupted country' and 'ugly governance', Indonesia had to receive potential consequences on economic development and foreign aid. Corruption lowered the economic growth of the states by reducing GDP and per capita income, and making poverty reduction efforts ineffective. It also misled the intended impact of the foreign aid programs because it created inhospitable environment for investors, reduced the quality of investment, and reduces the effectiveness of foreign aid programs. A state that is lack of international legitimacy on being democratic good governance will not be able to create an enabling environment for investment, working, saving, and business (Ang, 2011:16-17). Those arguments sum up that corruption could really hamper the economic development of a state.

Regaining back international legitimacy and trust from the international community is important as it will affect the trust from investors and donor agencies. When more investment is coming into the country, it will stimulate economic activity, and eventually it will lead to economic growth (Ang 2011, 16). To grow economically and 
to reach prosperity is every country's interest, and so is Indonesia's. OGP is expected to be a tool for Indonesia to achieve economic growth and prosperity.

Most aid institutions show a positive relationship between measurements of good governance and their aid allocations (Dollar and Levine, 2004 in Ang 2011, 17). Since the international demand for good governance and openness had been longing years before OGP, Indonesia's decision to join OGP is expected to gain support from the donor/aid agencies. Furthermore, Indonesia's involvement in OGP is also an investment for the support system and peer learning platform provided by OGP.

The interview statements from Tara Hidayat and Fithya Findie mentioned in the previous chapter confirmed that Indonesia's ability to create an enabling environment for investors was a concern to Indonesian government. Therefore, Indonesia's decision to join OGP was expected to be able to give long-term political and economic investment. With the features OGP has to offer, the opportunity to be on the spotlight, and potential positive on Indonesia's politic and economy, OGP is expected to add pressure to push good governance agenda, to be a momentum to gain Indonesia's international legitimacy as democratic good governance, and to create a longterm political and economic investment.

\section{Conclusion}

Based on the underlying factors above, the analysis of why Indonesia decided to join OGP was made upon three main arguments, which are (1) OGP is expected to add more pressure to push good governance agenda in Indonesia to combat corruption; (2) OGP as a momentum to strengthen Indonesia's international legitimacy after the negative implications because of corruption; and (3) OGP as longterm political and economic investment to help Indonesia wake up from corruption. From the analysis above, this research concludes that Indonesia's decision to join OGP was a transformative effort to deal with the impacts of corruption. 


\section{References}

\section{Book and Chapter in Book}

Hennida, Citra. 2015. Rezim dan Organisasi Internasional. Malang: Intrans Publishing.

Mujani, Saiful. 2006. Mengkonsolidasikan Demokrasi Indonesia. Jakarta: Lembaga Survei Indonesia.

\section{Journal and Online Journal}

Drury, A. Cooper, Jonathan Krieckhaus, and Michael Lusztig. 2006. "Corruption, Democracy, and Economic Growth," International Political Science Review, 27(121): 121-136.

Khan, Mohsin S. 1996. "Government Investment and Economic Growth in the Developing World," The Pakistan Development Review, 35(1): 419-439.

Weatherbee, Donald E. 2004. "Governance in Southeast Asia: the Good, the Bad, and the Ugly." In Growth E Governance in Asia, edited by Yoichiro Sato, 179-191. Honolulu, HI: Asia-Pacific Center for Security Studies.

\section{Online Article}

Bali Democracy Forum. "Why Do We Need Bali Democracy Forum?" [online] https://bdf.kemlu.go.id/about/why-bdf [accessed February 8, 2016].

Open Government Partnership. "OGP Eligibility Criteria." [online] http://www.opengovpartnership.org/how-it-works/ eligibility-criteria [accessed Octovber 25, 2016].

Transparency International "What is Corruption?". [online] http:// www.transparency.org/what-is-corruption/ [accessed May 11, 2016].

World Bank. "What is Fraud and Corruption?" [online] http:// www. worldbank.org/en/about/unit/integrity-vice-presidency/ what-is-fraud-and-corruption [accessed May 11, 2016].

Mangkusubroto, Kuntoro. Official Statement on OGP Declaration in New York, September 20, 2011. Courtesy of Open Government Indonesia, [online] http://blog.opengovindonesia. org/2016/09/20/indonesia-dan-ogp-deklarasi-ogp-20115yearsogp/ [accessed January 12, 2017].

World Bank Public Official Financial Disclosure [online]. http:// publicofficialsfinancialdisclosure.worldbank.org $/$ [accessed October 25, 2016].

World Bank Public Official Financial Disclosure [online] http:// publicofficialsfinancialdisclosure.worldbank.org/ [accessed 
October 25, 2016].

Metro TV News. "Pelayanan Buruk Pemerintah Daerah.", December 19, 2014. [online] http://news.metrotvnews.com/ read/2014/12/19/333862/8203-pelayanan-buruk-pemerintahdaerah [accessed May 19, 2016].

\section{Others}

Al'Afghani, Mohammad M. Phone Interview. October 31, 2016.

Ang, Amanda. 2011. "The Political Economy of Corruption Indexes." Master's thesis, University of Sydney.

Erawan, I Ketut P. n.d. "Reflecting Democratic and Peace Promotion in Asia: Bali Democracy Forum Framework," in UNDP Briefing. Bali: Institute Peace and Democracy.

Hidayat, Tara. Phone Interview. November 7, 2016.

Open Government Partnership. Articles of Governance 2012 (updated March 2014 and April 2015) [online] http://www. opengovpartnership.org/sites/default/files/attachments/ OGP\%20ArticlesGov\%20Apr\%2021\%202015.pdf [accessed April 8, 2015].

Sumarto, Sudarno, Asep Suharyadi, and Alex Arifianto. 2004. Governance and Poverty Reduction: Evidence from Newly Decentralized Indonesia. Edited by Kathryn Sadler and Nuning Akhmadi. Jakarta: SMERU Research Institute.

The Economist Intelligence unit "Democracy Index", [online] https://www.eiu.com/public/topical report. aspx?campaignid=Democracy0115 [accessed October 25, 2016].

The Right to Information: Good Law and Practice, [online] http:// right2info.org/ [accessed October 25, 2016].

Transparency International. Corruption Perception Index (Indonesia). 1995-2011.

Wirajuda, Muhammad H. 2014. “The Impact of Democratisation on Indonesia's Foreign Policy: Regional Cooperation, Promotion of Political Values, and Conflict Management." PhD diss., London School of Economics and Political Science, London. 